\title{
A Rare Cause of Epistaxis due to Leech Infestation: A Case Report
}

\author{
Epistaksisin Nadir Bir Sebebi Sülük Enfestasyonu: Olgu Sunumu
}

Yılmaz Zengin, Ercan Gündüz, Mustafa İçer, Recep Dursun, Hasan Mansur Durgun, Ahmet Gündüzalp, Mustafa Ekinci

Department of Emergency Medicine, Dicle University Faculty of Medicine, Diyarbakır, Turkey

\section{ABSTRACT}

Introduction: Leech infestations can lead to many symptoms, such as epistaxis, shortness of breath, obstruction of the upper respiratory tract, and hemoptysis. Leeches can often enter the body with drinking water or washing the mouth and nose.

Case Report: In this case report, we presented a patient who was mentally retarded and admitted to emergency medicine with complaints, such as intermittent epistaxis, nasal congestion, sore throat, and shortness of breath.

Conclusion: Finally, we understood that these symptoms were related to an oropharyngeal leech.

Keywords: Epistaxis, mental retardation, leech infestation Received: 06.03.2014 Accepted: 30.06.2014

\section{ÖZET}

Giriş: Sülük enfestasyonu epistaksis, üst solunum yolu obstrüksiyonu, hemoptizi ve nefes darlığı gibi semptomlara sebep olabilir. Sülükler genellikle su içerken veya yıkanırken ağız ve burundan girebilir.

Olgu Sunumu: Bu olguda aralıklı burun kanaması, burun tıkanıklığı, boğaz ağıısı ve nefes darlığı şikayetleri ile acil servise başvuran mental retarde bir hasta sunulmuştur.

Sonuç: Bu belirtilerin orofarinks bölgesine tutunan sülükten kaynaklandığı anlaşıımıştır.

Anahtar Kelimeler: Epistaksis, mental retarde, sülük enfestasyonu

Geliş Tarihi: 06.03.2014 Kabul Tarihi: 30.06.2014

\section{Introduction}

Leeches are rare blood-sucking endoparasites and live in unfiltered water or contaminated water, and they can cause potentially fatal complications (1). People generally can receive leeches into their bodies when using unfiltered or contaminated water to bathe, to drink, or to swim. Therewithal, they can be transmitted through the conjunctiva, cornea, vagina, vulva, and urethra. Leeches can pass from the mouth and nose to the epiglottitis, nasopharynx, and even the trachea and bronchi (2). They remain for days and weeks. The most prominent symptom is continuous bleeding from the mouth and nose in patients that have leech infestations, and the other symptoms are headache, fatigue, and discomfort. Leeches that go into the pharynx and larynx cause respiratory distress and can lead to death through the trachea or bronchi. The most common types of leeches are Hirudo medicinalis and Limnatis nilotica in people. Limnatis nilotica is the most common leech that has been reported in our country (3). In rural areas, people who are living in rural areas where drinking water from springs is a habit can take leeches in this way.

In this case report, we presented a patient who was mentally retarded and had a leech infestation in the nasopharynx that caused symptoms of epistaxis and obstruction of the upper respiratory system.

\section{Case Report}

A 19-year-old man who lived in a rural area presented to the emergency department with complaints of intermittent epistaxis, nasal obstruction, sore throat, and dyspnea for about 2 weeks. In the medical history of the patient, who had mental 

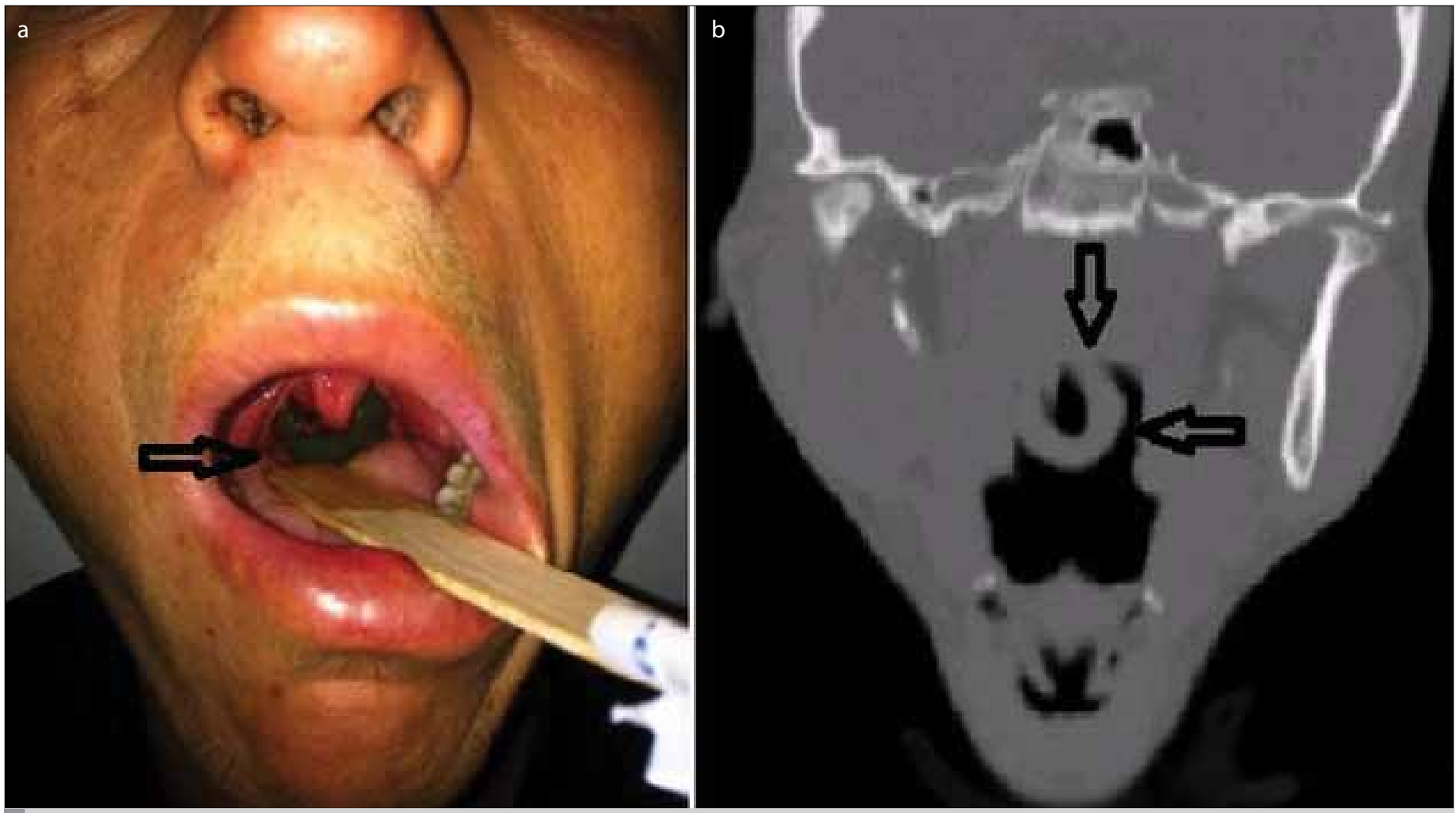

Figure 1. A gray green foreign body in the oropharynx (a), A coronal tomography section (b)

retardation, he was previously evaluated for these complaints in another medical center. Then, upper respiratory tract infection was diagnosed and discharged on prescription. The patient was admitted to the emergency department with complaints of nonregression of the symptoms. We learned from his family that he was living in a village and using unfiltered water from the spring occasionally. On physical examination, his general condition was moderate; he was conscious, but co-operation was limited. A moving gray green foreign body was seen in the oropharynx (Figure 1a). Other systemic examinations were normal. A neck tomography was scanned in order to determine the foreign body and its location. A single foreign body that extended to nasopharynx was observed on the coronal and axial tomography sections (Figure 1b). The patient was consulted by an otolaryngologist. The foreign body was removed with the help of forceps and understood to be a leech that measured nearly $6 \mathrm{~cm}$ in length (Figure 2). The patient was discharged from the emergency department after a few hours having no complications. We took his consent from the patient's father for publication of the case.

\section{Discussion}

Leeches can generally pass into the human body when using unfiltered water to bathe or to drink in rural areas (4). Abuhandan et al. (5) reported a 5-year-old patient, complaining of upper gastrointestinal bleeding due to a leech, who lived in the countryside and used unfiltered water. In our patient, we believe that the leech was taken into the body by drinking contaminated water.
Literature data indicate that leech infestations are seen in patients who are usually under 10 years and over 60 years old (4). Şengül et al. (4) reported three cases whose ages were 4, 8, and 65 years old and who had Alzheimer's disease. Our case was different from the literature, because he was 19 years old and had mental retardation. In our opinion, leech infestation is more frequent in patients who can not express themselves.

Leeches can be in any location from the larynx to the upper respiratory tract when they are taken into the body by drinking contaminated water (1). Nasal leech infestation is a major frequent form of leech endoparasitism (3). Güloğlu et al. (3) informed of infestation with two leeches in the nasopharynx and subepiglottic area. In our patient, the leech location was similar to the literature, too.

When leeches feed, they secrete hirudin for bleeding that can sustain for a long time, which supports the leeches to get complete food (1). Symptoms of leech infestation may differ regarding localization of the leeches. If a leech is located at the nasal cavity or nasopharynx, it may cause epistaxis, nasal obstruction, or the sense of an alien body moving around in the nose. When patients have a nasal leech infestation, their major symptom is recurring epistaxis. Leech infestation in the pharynx or esophagus may be a cause for painful swallowing. Other symptoms, such as hemoptysis, hoarseness, respiratory distress, and hematemesis, were also reported $(1,3)$. Estambale et al. informed of a Kenyan patient who was 3 years old, 


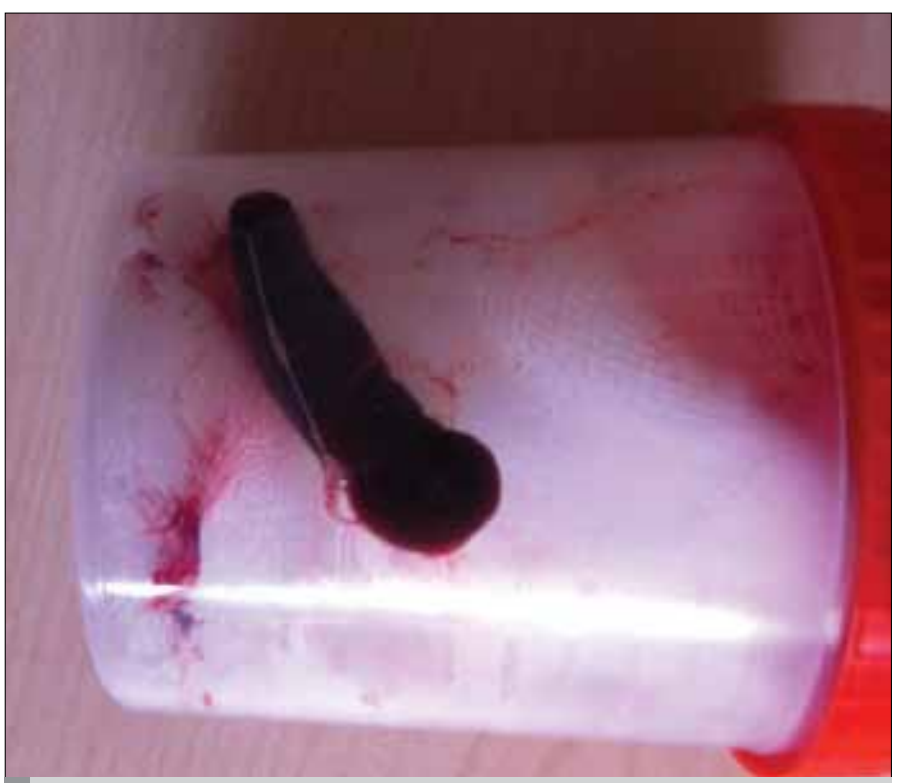

Figure 2. The leech was put in a box and measured nearly $6 \mathrm{~cm}$ in length

submitting with complaints of hematemesis and epistaxis (6). Bilgen et al. (7) reported a patient who complained of nasal obstruction and recurrent epistaxis for 4 months. We think that the symptoms of our patient, such as sore throat, respiratory distress, and intermittent epistaxis, were related to the leechıs location, which extended from the nasopharynx to oropharynx.

If the diagnosis of leech infestation is delayed, severe anemia and death due to asphyxia may occur (8). Direct or indirect laryngoscopy is used to diagnose leech infestation, and the leech can be removed $(1,3)$. When we use direct laryngoscopy to remove the leech, we may slog sometimes due to its strong adherence to the place and mucoid and fragile body, which ruptures easily (3). When the leech is close for catching with the hand or forceps, hypertonic saline solution may be given to the nasal cavity, and then, it can be caught and gently pulled out. Nasopharyngeal leeches can be removed by direct injection of 5\% cocaine or $4 \%$ lidocaine solution into the leech after it is paralyzed. In addition to this, different materials can help us to remove the leech prior to application, such as physiological saline, nit, oil of turpentine, and alcohol (3). The operation was performed by an otolaryngologist with indirect laryngoscopic examination, and the leech was removed from the pharynx with forceps. There was no complication due to removal of the leech.

\section{Conclusion}

Especially, leech infestation should be considered in some cases who are not fully able to express themselves, such as children and mentally retarded patients, live in a rural area, and use unfiltered water, and in unknown causes of the patient's complaints, like epistaxis, nasal congestion, sore throat, and dyspnea.

Informed Consent: Written informed consent was obtained from patient's father who participated in this case.

Peer-review: Externally peer-reviewed.

Author Contributions: Concept - Y.Z.; Design - Y.Z.; Supervision M.I.; Materials - R.D., E.G.; Data Collection and/or Processing - A.G.; Analysis and/or Interpretation - Y.Z.; Literature Review - Y.Z., H.M.D.; Writer - Y.Z.; Critical Review - M.I., H.M.D.

Conflict of Interest: The authors declared no conflict of interest.

Financial Disclosure: The authors declared that this study has received no financial support.

Hasta Onamı: Yazılı hasta onamı bu olguya katılan hastanın babasından alınmıştır.

Hakem Değerlendirmesi: Dış bağımsız.

Yazar Katkıları: Fikir -Y.Z.; Tasarım - Y.Z.; Denetleme - M.I.; Malzemeler - R.D, E.G..; Veri toplanması ve/veya işlemesi - A.G., M.E.; Analiz ve/ veya yorum - Y.Z.; Literatür taraması - Y.Z., H. M. D.; Yazıyı yazan - Y.Z.; Eleştirel İnceleme - M.I.., H.M.D.

Çıkar Çatışması: Yazarlar çıkar çatışması bildirmemişlerdir.

Finansal Destek: Yazarlar bu çalışma için finansal destek almadıklarını beyan etmişlerdir.

\section{References}

1. Kunduracıoğlu A, Karasu I, Afrashi A, Özsöz A, Çakan A, Aksel N. Larinkste sülük infestasyonuna bağlı hemoptizi. Solunum Dergisi 2009; 11: 134-6.

2. White GB. Leeches and leech infestation. In: Cook GC, ed. Manson's Tropical Disseases 20 th $e d$. London: Saunders; 1998. p.1523-5.

3. Güloğlu C, Al B, Özhasenekler A, Güllü N, Aldemir M. Üst solunum yolu obstruksiyonu, burun kanaması ve kronik aneminin nadir bir sebebi olarak sülük: Iki olguluk deneyimimiz. Tıp Araştırmaları Dergisi 2004: 2: 45-8.

4. Şengül E, Bakır S, Şengül CA, Erdur Ö. An unusual cause of epistaxis, anemia and upper respiratory tract obstruction Leeches: Report of three cases. J Clin Exp Invest 2012; 3: 401-3. [CrossRef]

5. Abuhandan M, Çalık M, Demir N, Ayçiçek A. Üst Gastrointestinal Kanamalı Hirudiniasis Vakası. JAEMCR 2012; 3: 91-2. [CrossRef]

6. Estambale BB, Knight R, Chunge R. Haematemesis and severe anemia due to a pharyngeal leech (Myxobdella Africana) in a Kenyan Child: a case report. Trans R Soc Trop Med Hyg 1992; 86: 458. [CrossRef]

7. Bilgen C, Karci B, Uluöz U. A nasopharyngeal mass: leech in the nasopharnyx. Int J Pediatr Otorhinolaryngol 2002; 64: 73-6. [CrossRef]

8. Krüger $\mathrm{C}$, Malleyeck I, Olsen $\mathrm{OH}$. Aquatic leech infestation: a rare cause of severe anaemia in an adolescent Tanzanian girl. Eur J Pediatr 2004; 163: 297-9. [CrossRef] 